\title{
SPÓR O PRAWO NATURALNE - KONCEPCJA PERSONALISTYCZNA I BIOLOGISTYCZNA
}

\begin{abstract}
W artykule podejmuje się problematykę prawa naturalnego, na tle sporu, jaki wywołała publikacja encykliki Humanae vitae Pawła VI. Zaprezentowano dwie koncepcje prawa naturalnego: personalistyczną (neotomistyczna), na której opiera się encyklika, oraz jedną z jej kontrpropozycji sformułowanej przez filozofującego biologa Wolfganga Wicklera. Pierwsza odwołuje się do koncepcji człowieka jako bytu osobowego, w którym natura jest „zintegrowana w osobie", bytu istniejącego w ciągłym rozwoju, poprzez istotowe ukierunkowanie na dobro osobowe jako ostateczny cel i motyw działania. Prawo naturalne interpretuje jako odbicie w rozumnej naturze człowieka odwiecznego (niezmiennego) porządku, rozumną inklinację ludzkiej natury do dobra współmiernego dla osobowego bytowania. Druga - tworzona przez Wicklera z pozycji krytyki wobec koncepcji „tradycyjnej” - uznaje fizyczno-duchową jedność ludzkiej natury, jednak fundamentalną dla osobowego życia sferę moralności opiera w istotnej mierze na gruncie biologicznych inklinacji, które stanowią jednocześnie swego rodzaju kryterium dobra moralnego. Rezultatem takiego rozumienia człowieka jest koncepcja prawa naturalnego o zmiennej treści (odpowiednio do ewoluującej natury biologicznej człowieka) oraz pewnego rodzaju biologizm etyczny (ugruntowanie prawa moralnego w prawie natury rozumianej biologicznie).

Problem prawa naturalnego, w sposób bardziej lub mniej uwyraźniony, jest wciąż obecny, zwłaszcza w społecznych i politycznych debatach dotyczących stanowienia prawa, przy czym stałym jednym z ich stałych punktów odniesienia jest jego „tradycyjna” koncepcja. W tym kontekście zadaniem artykułu jest jej przypomnienie, a jednocześnie przedstawienie jednej z kontrpropozycji, wpisującej się we współczesną argumentację za „nowoczesnym” rozumieniem prawa naturalnego.
\end{abstract}

Słowa kluczowe: prawo naturalne, prawo naturalne, natura człowieka, personalizm neotomistyczny, biologizm.

\section{WSTĘP}

Problem prawa naturalnego może się obecnie wydawać nieco przebrzmiały. Zagadnieniem tym w różnych ujęciach zajmowano się właściwie od początków

${ }^{1}$ Dr Beata Petrecka, Zakład Współczesnych Procesów Społeczno - Ekonomicznych w Europie, Instytut Stosunków Międzynarodowych, Państwowa Wyższa Szkoła Techniczno - Ekonomiczna w Jarosławiu, ul. Czarnieckiego 16, 37-500 Jarosław, tel. 166244640.

${ }^{2}$ Mgr Urszula Pietrzyk, Zakład Gospodarki Turystycznej i Hotelarstwa, Instytut Stosunków Międzynarodowych, Państwowa Wyższa Szkoła Techniczno - Ekonomiczna w Jarosławiu, ul. Czarnieckiego 16, 37-500 Jarosław, tel. 1662446 40, autor korespondencyjny, e-mail: uokulanis@ interia.pl

3 Dr Justyna Stecko, Zakład Nauk Humanistycznych, Wydział Zarządzania, Politechnika Rzeszowska, ul. Poznańska 1, 35-084 Rzeszów, tel. 178651204. 
racjonalnej myśli ludzkiej, a swój renesans przeżywało w XIX i XX w. To właśnie w tym czasie nastąpiły dwa „odrodzenia prawa naturalnego”. Szczególnie drugie odrodzenie, które w 1968 r. zainicjowała encyklika Pawła VI Humanae Vita, wzbudziło ogromną dyskusję, w której przez wiele lat uczestniczyli przedstawiciele różnych nauk - filozofii, teologii, socjologii, psychologii, biologii itp. Obecnie ten szeroki i bardzo wówczas intensywny dyskurs z pewnością przygasł, przynajmniej w obszarze głównych zagadnień podejmowanych na terenie filozofii. Niemniej problem prawa naturalnego - bardziej lub mniej wyraźnie, w sposób bardziej lub mniej uświadomiony - wciąż jest obecny, choć może bardziej w życiu społecznym i licznych dyskusjach politycznych niż na gruncie refleksji naukowej. Widoczny jest między innymi w dyskusjach dotyczących stanowienia prawa przyznającego coraz większe swobody, ale też programów edukacji szkolnej. Zauważyć można wówczas niemało odwołań do „tradycyjnej” koncepcji prawa naturalnego, głównie związanej z nauczaniem Kościoła i opartej na personalistycznej wizji człowieka, a z drugiej strony - z perspektywy oponentów - do ujęć nabudowanych na naukach szczegółowych (socjologicznych, psychologicznych, przyrodniczych) czy wprost na ideologii. Spór jest szczególnie ważny, ponieważ u jego podstaw jawi się określona koncepcja człowieka, jego osobowej godności, koncepcja dobra i określona formuła moralności. Sytuacja ta - jak można przyjać - wskazuje na rangę zagadnienia prawa naturalnego we współczesnym społeczeństwie lub - jeśli można zaryzykować takie stwierdzenie - na ciągłą aktualność tego problemu.

Trudno o pełne zaprezentowanie różnorodnych stanowisk wobec kwestii prawa naturalnego w krótkim artykule. Zdecydowano się więc na istotne ograniczenia. Pozostawiono główny schemat toczonych niegdyś i wciąż kontynuowanych dyskusji: z jednej strony personalizm i tradycyjna koncepcja prawa naturalnego (jako punkt odniesienia sformułowany w encyklice Humanae vitae), a z drugiej strony - opozycja zarzucająca temu podejściu izolację w stosunku do współczesnych osiągnięć nauki, aktualnych potrzeb społecznych. W tym drugim przypadku również dokonano znacznego ograniczenia - odwołano się do koncepcji jednego z ważniejszych krytyków tradycyjnej koncepcji prawa naturalnego, filozofującego biologa, Wolfganga Wicklera. Wickler stanął w gronie ostrych krytyków encykliki Pawła VI, stawiając jednocześnie własną kontrpropozycję. Encyklika Pawła VI dotyczy zasad moralnych w dziedzinie przekazywania życia, jednak ,tłem” wypowiedzi papieża jest wyraźnie zarysowany obraz całej koncepcji prawa naturalnego w takiej postaci, w jakiej proponuje ją filozofia neotomistyczna. Z kolei Wickler, krytycznie analizując stanowisko Pawła VI w sprawie zasad moralnych dotyczących przekazywania życia, odnosi się wprost do „tradycyjnego" rozumienia prawa naturalnego i jednocześnie tworzy własną propozycję. Te właśnie dwie koncepcje rozumienia prawa natury - z pominięciem szczegółowych zagadnień - zostaną zaprezentowane.

\section{PERSONALISTYCZNA TEORIA PRAWA NATURALNEGO}

Prawo naturalne to, najogólniej mówiąc, przejaw natury ludzkiej rozumianej jako jego jedność duchowo-cielesna. Te dwa aspekty, cielesny i duchowy, są w ludzkim bycie nierozerwalne, jednak przede wszystkim człowiek jest istotą rozumną. W tym wymiarze bycia mieści się bowiem to, co istotnie odróżnia go od innych bytów - rozumność i wolność. Nadają one szczególny wymiar ludzkiemu bytowi, a jednocześnie pozwalają na 
odróżnienie w nim sfery dziania się, w którym „brak jest sprawczego twórczego czynnika osoby"4 od działań, a więc czynów osoby z udziałem woli świadomie kierowanej. Ontyczna jedność człowieka wyraża się w jedności jego natury, nie można więc ograniczyć jej rozumienia do jednej ze stron ludzkiego bytu. Nie ma w nim osobno natury biologicznej i duchowej, natura (w znaczeniu funkcji biologicznych) jest - jak to ujął Karol Wojtyła - ,zintegrowana w osobie",

$\mathrm{Na}$ tym też zasadza się specyficzne rozumienie prawa naturalnego. Nie jest ono bowiem zwykłą prawidłowością przyrody, której człowiek biernie podlega (jak zwierzęta), lecz prawem „na miarę” jego ontycznej struktury osobowej. Święty Tomasz określa je jako participatio legis aeternae in rationali creatura ${ }^{6}$. Definicja ta wskazuje jednocześnie na źródłowy i normatywy charakter prawa naturalnego. Jest to porządek „wcześniejszy” od rozumu, niekonstytuowany twórczo przez niego. Z kolei nie można się go wyrzec, zmienić, można natomiast - i to jest dane człowiekowi jako rozumnowolitywnej istocie - odczytać. Prawo naturalne jest pewnego rodzaju odbiciem (partycypacja) w rozumnej naturze człowieka odwiecznego porządku (ładu), a jego podstawowym wyrazem jest ludzka inklinacja ku dobru. Co istotne, jawi się ono jako dane (nie stworzone przez człowieka), ale jednocześnie nie narzucone z zewnątrz, lecz wypływające z samego ,wnętrza” bytowości człowieka, obecne w jego naturze. Jak pisze Mieczysław Krąpiec: „owo właśnie «odbicie» - partycypacja (tak bierne przez fakt stworzenia natury, jak i czynne poprzez autodeterminację do określonych dóbr) prawa odwiecznego w ludzkiej naturze rozumnej jest analogicznie ogólnym prawem naturalnym, czyli prawo naturalne jest rozumną inklinacją ludzkiej natury do współmiernego dla człowieka dobra", Ta rozumna inklinacja wyraża się w fundamentalnej normie prawa naturalnego: bonum est faciendum, malum vitandum.

Takie rozumienie prawa naturalnego ukazuje jego ogólność, ale w pewien sposób również podstawowy wymiar w stosunku do moralności i prawa moralnego. Istotą moralności jest bowiem ludzka decyzja kierowana rozumem w perspektywie dobra. Mieczysław Krapiec pisze: „Mając na uwadze fakt, że [...] każdy ludzki uczynek świadomy i dobrowolny nie może być obojętny w stosunku do dobra, bo jest ono realizowaniem dobra, którego człowiekowi jako bytowi przygodnemu brak - widzimy, że każdy ludzki uczynek, decyzja jest realizowaniem prawa naturalnego. Jeśli bowiem prawo naturalne uświadamiamy sobie w postaci praktycznego sądu: «dobro należy czynić», to każdy czyn jest realizowaniem dobra osobowego, czyli uczynkiem dokonywanym właśnie pod wpływem prawa naturalnego" ${ }^{\text {. }}$. W tym sensie wybór dobra jest aplikacją ogólnej normy prawa naturalnego do konkretnych sytuacji (ludzkich wyborów moralnych). Jako takie prawo naturalne jest jednocześnie prawem moralnym, a normy prawa moralnego są pewnym jego uszczegółowieniem.

Kwestią podstawową dla rozumienia prawa naturalnego jest jego niezmienność i powszechność. Niezmienność odzwierciedla samo określenie lex aeterna - prawo

\footnotetext{
${ }^{4}$ K. Wojtyła, Osoba ludzka a prawo naturalne, ,,Roczniki Filozoficzne” XVIII/2 (1970), s. 54.

${ }^{5}$ Ibidem, s. 54.

${ }^{6}$ Św. Tomasz, Summa theologica, I-II, q. 91, a. 2.

${ }^{7}$ M. Krapiec, O tomistycznq koncepcje prawa naturalnego, [w:] W nurcie zagadnień posoborowych, red. B. Bejze, t. 2, Warszawa 1995, s. 20.

${ }^{8}$ M. Krapiec, Człowiek i prawo naturalne, Lublin 1975, s. 217, oraz por. M. Krapiec, Człowiek $i$ prawo naturalne, Lublin 2009.
} 
wieczne. W ujęciu tomistycznym ostatecznym gwarantem niezmienności prawa naturalnego jest Bóg (Absolut - Najwyższy Prawodawca). Można jednak na ten problem spojrzeć od strony jedności prawa naturalnego i natury ludzkiej. Jako naturalne jest „zakotwiczone” w naturze ludzkiej, stanowi jej inklinację. Natura ta natomiast, mimo jej dynamiki, jest w wymiarze osobowego bycia niezmienna - niezmienne są bowiem istotowe elementy konstytutywne osoby jako osoby, niezmienne są zatem również istotowe elementy rozumnej natury człowieka. Zmiana w tym zakresie oznaczałaby zarazem zmianę istotnych treści człowieczeństwa. Warto przy tym przypomnieć, że natura rozumiana przyrodniczo jest w osobie zintegrowana. Jeśli więc nawet uległaby zmianie (w sferze biologicznej), to nie oznacza to zmiany samej istoty bycia człowiekiem (osoba), nie zmienia się $w$ konsekwencji również dobro specyficznie osobowe i przyporządkowanie do tego dobra wyrażone w prawie naturalnym.

Niezmienne prawo naturalne i uszczegółowiające je normy moralne realizowane są jednak w zmieniającej się rzeczywistości. Nie oznacza to w żadnej mierze ich relatywności, a jedynie ich kolejne uszczegółowienia odpowiednio do zmieniających się realiów. „Rzecz w tym - pisze Tadeusz Ślipko - że w graniach społecznego życia ludzkiego nie od razu zostały urzeczywistnione wszystkie warunki, od których zależą szczegółowe zastosowania określonych norm prawa naturalnego. Dochodzą one do głosu w miarę rozwoju ludzkości, a tym samym stwarzają przesłanki dla równoczesnej ewolucji w świecie wartości moralnych i imperatywów"9. Podobnie rzecz przedstawia się z zakresem wolności osobistych na przestrzeni różnych historycznych układów społecznych. Ewolucyjne przemiany w prawie naturalnym są tutaj jego dopełnianiem się „W sferze jego zastosowań do bogacących się nieustannie form życia społecznego i indywidualnego" ${ }^{\prime 10}$. Nie chodzi więc o zmianę istotnych treści norm prawa naturalnego $\mathrm{i}$ „osadzonych” na nich norm moralnych, lecz o ich uszczegółowienie.

Termin „ewolucja” nie jest w odniesieniu do prawa naturalnego najlepszy. Lepiej byłoby mówić o dynamizmie prawa naturalnego. Takie określenie zwraca uwage na związek z dynamicznym charakterem ludzkiej natury. Istotnym wymiarem bycia człowieka jest jego przygodność, wyrażająca się w potrzebie ciągłego rozwoju, „uzupełniania się dobrem”,", budowania własnej doskonałości, która nie kłóciłaby się z jego sumieniem, a więc jednocześnie z ładem wypływającym z natury człowieka. Prawo naturalne przybiera tu postać ukierunkowania, dynamizowania bytu człowieka ku moralnemu wzrostowi.

Drugi problem - powszechność prawa naturalnego - odwołuje pośrednio do kwestii jego poznania. Tu również uwypukla się jego „naturalny wymiar”. Prawo natury bowiem „człowiek poznaje rozumem, jest ono proste, wręcz narzucające się. [...] Rozeznaje je każdy normalny człowiek, choćby skądinąd najprymitywniejszy" "12. Nie oznacza to, aby normy prawa naturalnego były wrodzone i raz na zawsze dane człowiekowi w postaci samoobjawiających się reguł postępowania. Człowiek sam je formułuje, wysiłkiem swojego rozumu każdorazowo odróżniając dobro od zła. Nie znosi to jednak niezmienności prawa naturalnego. Zmienia się wprawdzie stopień poznania (zwłaszcza

\footnotetext{
${ }^{9}$ T. Ślipko, Zarys etyki ogólnej, Kraków 1974, s. 262-263, oraz por. wyd. 5: Zarys etyki ogólnej, Wydawnictwo WAM, Kraków 2009.

${ }^{10}$ Ibidem, 263.

${ }^{11}$ A. Krąpiec, O tomistycznq koncepcje prawa naturalnego..., s. 25.

${ }^{12}$ K. Wojtyła, Elementarz etyczny, Lublin 1999, s. 59-60.
} 
przez coraz pełniejsze poznanie własnej natury przez człowieka), ale normy prawa naturalnego wciąż pozostają obiektywnymi, niezmiennymi imperatywami.

Wskazuje to na powszechność prawa naturalnego. Swoim zasięgiem obejmuje ono wszystkich ludzi, nikt bowiem nie jest zwolniony z jego przestrzegania, a jednocześnie każdy w pewien sposób jest ,skazany” na jego nieustanne rozpoznawanie. W tym też tkwi swego rodzaju dramat człowieka zarówno w jego indywidualnej, jak i społecznej formie życia. Ogólną normę prawa naturalnego musi on bowiem ,uzgadniać” w procesie poznania świata i własnej natury, siebie samego jako osoby nakierowanej właściwą jej dynamiką na osobowe dobro.

\section{WICKLERA ROZUMIENIE CZLOWIEKA I PRAWA NATURY}

W rozumieniu Wicklera natura człowieka jest jedna, ale złożona: „,Z dwóch istotnych elementów, to jest $\mathrm{z}$ materialnego ciała i niematerialnej duszy"13. Pierwszy element stanowi stronę fizyczną natury, wspólną człowiekowi i zwierzętom. W nim mieszczą się skłonności naturalne, popędy, instynkty, wszystkie doświadczane przez człowieka mechanizmy i prawidłowości biologiczne ${ }^{14}$, czyli to wszystko, o czym Karol Wojtyła mówił, że ,dzieje się w człowieku”.15. Drugi element natomiast to natura „metafizyczna”, po jej stronie mieści się rozumność, wolna wola - to wszystko, co w człowieku duchowe. Ona decyduje o tym, że człowiek jest odmienny od zwierząt, że jego zachowanie jest zachowaniem istoty rozumnej, a jednocześnie pozwala zapanować na naturalnymi skłonnościami, czyli naturą w przyrodniczym rozumieniu ${ }^{16}$. Jedność natury widoczna jest w działaniu, które „uruchamia” jej obydwie strony, a człowiek może korzystać i z jednego, i drugiego elementu. Tak rozumiana natura człowieka, dwustronna, choć jedna, jest podstawą określenia prawa natury (naturalnego). Wydaje się jednak, że podstawowe znaczenie Wickler przypisuje stronie fizycznej.

Złożoność natury wskazuje według Wicklera na to, że prawo natury można ustalać na dwa sposoby, przy czym każdą ze stron natury powinno się badać oddzielną, właściwą dla niej metodą. Dla strony fizycznej adekwatne są metody przyrodnicze, dla metafizycznej natomiast - wymykającej się ścisłym metodom badawczym, ale ujmowanej we „własnym bezpośrednim doświadczeniu" $" 17$ - odpowiednie będą metody filozoficzne. Ponieważ natura człowieka jest jedna, zarówno metoda przyrodnicza, jak i filozoficzna prowadzić powinny do uzyskania takiego samego wyniku - wspólnego obrazu prawa naturalnego. Rezultaty poznania z zastosowaniem obu metod (filozoficznej i przyrodniczej) są jednak rozbieżne, wobec tego jedna $\mathrm{z}$ nich zawodzi -oznacza to również, że jedna $\mathrm{z}$ tych dwu dziedzin poznania jest niekompetentna w ustalaniu prawa natury obowiązującego człowieka bezwzględnie.

Przyrodoznawstwo bazuje na empirycznej sprawdzalności twierdzeń. „Wypowiedź z zakresu biologii - pisze Wickler - jest prawdziwa, gdy pasuje do żywej istoty, gdy jest

\footnotetext{
${ }^{13}$ W. Wickler, Czy jesteśmy grzesznikami? Prawa naturalne matżeństwa, Warszawa 1974, s. 38.

${ }^{14}$ Ibidem, s. 30.

${ }^{15}$ K. Wojtyła, Osoba i czyn, Kraków 1985, s. 93; por także: M. Zięba, Jestem z Wami: kompendium twórczości i nauczania Karola Wojtyły - Jana Pawła II, Kraków 2010.

${ }^{16}$ W. Wickler, Ethologie Und Ethik - Normenfindung oder Normenkritik?, [w:] Naturgesetz und christliche Ethik. Zur wissenschaftlichen Disskusion nach Humanae vitae, Munchen 1970, s. 101.

${ }^{17}$ W. Wickler, Czy jesteśmy grzesznikami..., s. 52.
} 
dostosowana do jej natury" 18 . W przeciwnym razie to żywe istoty nie pasują do metody. Prawda twierdzeń biologicznych w oparciu na doświadczeniu jest prosta do weryfikacji, a odkryte w świecie zwierząt prawidłowości dają się zastosować do człowieka. Owszem, nie można na człowieka przenosić wyników badań nad zwierzętami, można jednak przenosić hipotezy robocze ${ }^{19}$. Przykładem takiej hipotezy jest prawidłowość życia społecznego: „Im bardziej różnią się miedzy sobą zwierzęta, które niezależnie od siebie przebyły równolegle tę samą drogę rozwoju, a jednocześnie objawiają w inwentarzu właściwych sobie zachowań tę samą zasadę konstrukcyjną wysoko rozwiniętego życia społecznego - tym większej możemy nabrać pewności, że odnaleźliśmy obowiązującą w badanej kategorii stworzeń prawidłowość naturalną. Ponieważ człowiek zalicza się pod względem biologicznym do kręgowców i żyje zarówno w trwałych związkach par, jak i większych formacjach grupowych, owa naturalna prawidłowość powinna obowiązywać i jego" 20 .

Z kolei metoda, którą posługuje się teolog lub filozof, jest zdaniem Wicklera co najmniej watpliwa. Dowodem na to jest wyłożona przez Pawła VI w encyklice Humanae Vitae koncepcja prawa naturalnego - niezgodna w ocenie Wicklera z wynikami badań nauk przyrodniczych, czy mówiąc inaczej - z naturą człowieka widzianą z perspektywy prawidłowości biologicznych. Skoro w encyklice zaproponowana koncepcja prawa naturalnego kwestionuje oczywiste wyniki nauk biologicznych, to nie zgadza sie z faktami, a to oznacza, że nie wypływa z faktów, lecz z ,teologicznego mamidła" ${ }^{21}$. Wobec tego albo teologowie będą mówić o prawie naturalnym w oparciu na metodzie biologicznej, albo o jakimś innym prawie, jeżeli chcą, aby ich wypowiedzi były niezależne od aktualnego stanu wiedzy empirycznej ${ }^{22}$.

Wickler wyraźnie przyjmuje metodę przyrodniczą jako podstawową do wyznaczania prawa całej natury człowieka w obu jej stronach. Nauki przyrodnicze, w szczególności biologia, nie ograniczają się tylko do wskazania tego, co biologicznie użyteczne człowiekowi, potrafią również ,sprawdzić ustanowione normy etyczne pod kątem ich zgodności z prawami biologii”"23. Gdyby biologia nie była do tego zdolna, to trzeba byłoby przyjąć jakąś ,,abstrakcyjną metafizyczną naturę człowieka" ${ }^{24}$, która wykluczałaby jej stronę fizyczną, z czym Wickler nie może się zgodzić, bo taki obraz natury wyklucza jej stronę fizyczną. Metoda filozoficzna nie jest w stanie objąć całej natury człowieka, ogranicza się jedynie do jej strony „metafizycznej”, i może - owszem - odkrywać prawa rządzące tylko tą stroną natury. Gdyby jednak okazało się, że są one inne niż odkrywane metodą przyrodniczą, powinno się je przyporządkować wynikom przyrodoznawstwa.

Adekwatnie do wyróżnionych części natury człowieka - fizycznej i metafizycznej - a równocześnie do metod, które są im przyporządkowane, Wickler wyróżnia dwa prawa rządzące naturą człowieka. Jedno, dotyczące fizycznej strony, nazywa naturalnym, drugie - obejmujące metafizyczną stronę natury - ludzkim. Prawo naturalne dotyczy skłonności natury człowieka do zachowania życia indywidualnego, przekazywania życia oraz życia

\footnotetext{
18 Ibidem, s. 52.

${ }^{19}$ Ibidem, s. 326

${ }^{20}$ Ibidem, s. 279.

${ }^{21}$ Ibidem, s. 331.

${ }^{22}$ Ibidem, s. 241.

23 Ibidem, s. 29.

${ }^{24}$ Ibidem, s. 23.
} 
społecznego. Właściwie zawiera się w nim to wszystko, co najpierw rejestruje etologia w stosunku do życia zwierząt, a potem próbuje zestawić, pogrupować w pewne prawidłowości zależnie od różnych czynników, które mają wpływ na zachowanie się zwierzęcia. Zakładając wspólną ze zwierzętami stronę fizyczną natury człowieka, Wickler mówi o tym samym prawie naturalnym u człowieka co u zwierząt. Zastrzega jednak, że nie ma zamiaru zoomorfizować człowieka, a skuteczną przed tym obroną jest obecna w naturze człowieka druga jej strona - „metafizyczna”. Do niej odnosi się prawo ludzkie określane w naukach filozoficznych. Dzięki takim specyficznym cechom człowieka, jak rozumność i wolność, różni się ono od prawa naturalnego.

Oba prawa kierują postępowaniem człowieka, niemniej - jak zauważa Wickler „etologia nie jest nauką o tym, co etyczne”, ${ }^{25}$, a także: „Instynktowne zachowanie się pod względem moralnym jest obojętne, ocenie podlega decyzja rozumu bądź sumienia, owej ostatecznej instancji, której orzeczenie dla każdego człowieka jest bezwzględnie wiążące"26. Stąd problem, który Wickler formułuje: „Jak natura i etyka ze sobą harmonizują?"27.

Zadanie filozofii, ściśle etyki, polega na ustalaniu pewnych ogólnych norm, w które biologia może wpisywać swoje prawa. Taką normą, która nie przekroczy granic metafizycznej strony ludzkiej natury posługującej się rozumem, jest norma „Należy czynić dobro”. Jest to właściwie jedyna norma, którą samodzielnie może sformułować filozofia. Ze względu jednak na swą ogólność nie jest zrozumiała. „Całkiem abstrakcyjne normy - czyń dobro, unikaj zła - nie wystarczały nie tylko następcom Tomasza, nie wystarczają też dzisiaj. Nauki przyrodnicze i nauki o zachowaniu się nie są z pewnością wezwane do krytyki tych całkiem abstrakcyjnych norm, może jednak do krytyki normatywnych przepisów zachowania; albo wtedy jak z właściwych norm przepisy te zostały wyprowadzone"28. Etyka więc może formułować tylko prawa w postaci schematów bez treści, normy treściowo „puste”. Takiego typu niezależne funkcje przydzielił Wickler w swej koncepcji metafizycznej stronie natury człowieka, na tym jej właściwa rola się kończy, a to, co może ona przekazać, praktycznie nic nie wyraża. Tym bowiem, co ukierunkowuje działania człowieka, są skłonności biologiczne.

W rezultacie nauki przyrodnicze stanowią bazę, z której powinna czerpać etyka, aby te „puste ramy” zapełnić i stać się zrozumiałą. A ponieważ biologiczna strona natury jest zmienna, w swojej treści zmienne są też normy moralne, czyli - mówiąc językiem Wicklera - normatywne przepisy zachowania. Moment współegzystencji etyki i biologii widzi on zasadniczo jako wypełnienie ,pustych ram” metafizycznych biologiczną treścią. Jest to jednocześnie moment jedności strony fizycznej i metafizycznej natury człowieka. Dopiero po poznaniu prawa fizycznej strony natury ,można podjąć próbę udoskonalenia jego realizacji przy użyciu środków człowiekowi właściwych"29. Wtedy też sensu nabierze norma: „Należy czynić dobro”.

U podstaw tego stanowiska tkwi uznanie zgodności działań człowieka z biologicznym wymiarem natury za kryterium dobra moralnego. Wickler zwraca uwagę na to, że natura człowieka jest skonstruowana dobrze (powołuje się tutaj na mądrość Stwórcy), dobre więc

\footnotetext{
${ }^{25}$ Ibidem, s. 42.

${ }^{26}$ Ibidem, s. 37.

${ }^{27}$ Ibidem, s. 36.

${ }^{28}$ W. Wickler, Ethologie Und Ethik, s. 100-101.

${ }^{29}$ W. Wickler, Czy jesteśmy grzesznikami, s. 57.
} 
są skłonności naturalne. Inaczej bowiem trzeba by przyjąć, że człowiek jest wadliwą konstrukcją i ,aby czynić dobrze, musi tę konstrukcję stale zwalczać"30. Działanie wbrew ludzkiej naturze, to jest biologicznie zdeterminowanym skłonnościom, jest działaniem złym $^{31}$. Dlatego człowiekowi pozostaje przyczyniać się do doskonalenia realizacji tychże skłonności naturalnych, a w tym celu ma wykorzystać rozum. W różny sposób, bo jest tu miejsce na wolną wolę człowieka, która dokonuje wyboru sposobu posłużenia się rozumem, ale poniekąd w graniach wyznaczonych naturą biologiczną. Podstawowe kryteria, jakimi wolna wola ma czy powinna się kierować, dokonując wyborów, to użyteczność, szybkość, łatwość, prostota wykonania, skuteczność. Są to doskonałości prakseologiczne. Chodzi więc o to, aby skłonności człowieka były zaspokajane w miarę jak najskuteczniej, najprościej, najszybciej. Wówczas to rozum ad hoc, w danej chwili formułuje nakaz: „To mi wolno zrobić, ponieważ dzięki temu moja potrzeba zostanie zaspokojona w sposób możliwie najprostszy, dla mnie wobec tego najkorzystniejszy. Decyzja rozumu, postrzeganego tutaj jako sumienie, jest decyzją ostatecznej instancji, jej

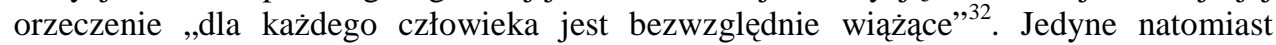
ograniczenie sposobu realizacji własnych skłonności naturalnych wynika ze społecznego charakteru ludzkiego życia. Pewną granicą jest drugi człowiek, niemniej jest to specyficzna granica. Na przykładzie życia małżeństwa Wickler tak ją charakteryzuje: „każdy człowiek musi sam rozstrzygać - pod kątem wymagań wzajemnej miłości w swoim małżeństwie - co mu jest dozwolone w zakresie tak zwanego flirtu pozamałżeńskiego tworzącego więź społeczną,"33. Dozwolone jest to wszystko, „,co tej więzi służy, nie urażając niczym godności i waloru ani człowieka, ani miłości [...], nawet jeżeli stanowi ingerencję w biologiczny przebieg rozrodu, ingerencję, która pozwoli na swobodne kształtowanie [...] naturalnych możliwości owej więzi”34.

\section{UWAGI KOŃCOWE}

Wicklerowską koncepcję natury człowieka i prawa naturalnego można by zaliczyć do szeroko rozumianego nurtu redukcjonistycznego. Uznaje on wprawdzie fizycznoduchową jedność ludzkiej natury, jednak fundamentalną dla osobowego życia sferę moralności opiera $\mathrm{w}$ istotnej mierze na gruncie biologicznych uwarunkowań. Wickler przyjmuje, że strona duchowa człowieka panuje (lub jest w stanie panować) nad fizyczną, ale panowanie to ostatecznie sprowadza się do podporządkowania się biologicznej stronie człowieka w postępowaniu mierzonym wartością dobra i zła moralnego. Neotomistyczny personalizm widzi w człowieku jedność duchowo-fizyczną, w której dusza przejawia swe istnienie i działanie przez ciało i wnosi w nie aspekty życia duchowego. To dzięki niej człowiek stanowi byt osobowy, który transcenduje świat przyrody, również własne uwarunkowania biologiczne, stanowi byt wewnętrznie zdynamizowany, w ciągłym rozwoju, przez istotowe ukierunkowanie na dobro osobowe jako jej ostateczny cel i motyw działania. W tym kontekście doskonalenie się człowieka wybiega istotnie poza samą zgodność z biologicznymi inklinacjami całościowo wziętego bytu ludzkiego. W

\footnotetext{
${ }^{30}$ Ibidem, s. 36.

${ }^{31}$ Ibidem, s. 39

32 Ibidem, s. 37.

${ }^{33}$ Ibidem, s. 330.

${ }^{34}$ Ibidem, s. 321.
} 
ujęciu Wicklera natomiast osoba nie tyle transcenduje siebie, co raczej redukuje do sfery naturalnych (biologicznych) inklinacji.

Fundamentalnym problemem jest $\mathrm{w}$ tym kontekście status prawa naturalnego. $\mathrm{Z}$ pewnym uproszczeniem można powiedzieć, że Wickler zaproponował koncepcję prawa o zmiennej treści (odpowiednio do ewoluującej natury biologicznej człowieka), co ostatecznie prowadzi do relatywizmu etycznego. Z kolei należałoby zapytać, czy w ogóle może być tutaj mowa o prawie naturalnym czy może raczej o pewnej prawidłowości natury, której przypisano szczególną rolę w życiu moralnym człowieka i jego doskonaleniu się - rolę kryterium rozstrzygającego o tym, czy postępowanie człowieka jest dobre czy złe moralnie. W tej sytuacji można by również sugerować, że mamy tutaj do czynienia z pewną odmianą biologizmu etycznego.

Sprawą dużej wagi jest również pewna dyskredytacja poznania filozoficznego i przyznanie naukom szczegółowym większej wartości poznawczej w odniesieniu do poznania prawa naturalnego, określenia porządku dobra i zła moralnego. Pomijając zasadność takiego stanowiska, warto podkreślić, że jest to sprowadzenie zagadnienia etycznego $\mathrm{z}$ porządku refleksji istotowej do porządku poznania aspektowego i relatywnego.

Koncepcja Wicklera jest jedną $\mathrm{z}$ wielu propozycji budowanych $\mathrm{w}$ opozycji do tradycyjnego pojmowania prawa naturalnego, a jako taka stanowi również pewnego rodzaju próbę odrzucenia stałego, niezmiennego porządku moralnego. Trudno dostrzec jej bezpośrednie odzwierciedlenie w sporach toczonych dzisiaj. Niemniej trzeba podkreślić, że przynajmniej jej niektóre elementy są obecne w stanowiskach i sposobach argumentacji przeciwników prawa naturalnego w jego tradycyjnym lub personalistycznym ujęciu. $Z$ pewnością należą do nich odwołanie się do wyników badań nauk szczegółowych, redukcjonistyczna koncepcja człowieka ograniczająca znacznie jego osobowy wymiar czy relatywizm wyrażający się w poszukiwaniu treści norm moralnych w nietrwałych (społecznych czy biologicznych) podstawach życia człowieka i społeczeństwa.

\section{LITERATURA}

[1] Krapiec M., Cztowiek i prawo naturalne, Lublin 1975 oraz Lublin 2009.

[2] Krapiec M., O tomistyczna koncepcje prawa naturalnego, [w:] W nurcie zagadnień posoborowych, red. B. Bejze, t. 2, Warszawa 1995.

[3] Ślipko T., Zarys etyki ogólnej, Kraków 1974.

[4] Św. Tomasz, Summa theologica, I-II, q. 91.

[5] Wickler W., Czy jesteśmy grzesznikami? Prawa naturalne matżeństwa, Warszawa 1974.

[6] Wickler W., Ethologie Und Ethik - Normenfindung oder Normenkritik?, [w:] Naturgesetz und christliche Ethik. Zur wissenschaftlichen Disskusion nach Humanae vitae, Munchen 1970.

[7] Wojtyła K., Elementarz etyczny, Lublin 1999.

[8] Wojtyła K., Osoba i czyn, Kraków 1985.

[9] Wojtyła K., Osoba ludzka a prawo naturalne, ,Roczniki Filozoficzne” XVIII/2 (1970)

[10]Zięba M., Jestem z Wami: kompendium twórczości i nauczania Karola Wojtyty Jana Pawta II, Kraków 2010. 


\section{DISPUTE ABOUT NATURAL LAW - PERSONALISTIC AND BIOLOGISTIC}

\section{CONCEPT}

The article takes up the issue of natural law, against the background of the dispute caused by the publication of the encyclical Humanae Vitae by Pope Paul VI. Two concepts of natural law were presented: the personalistic (neo-thomistic), upon which the encyclical is based, and one of its counterproposal formulated by the philosophizing biologist Wolfgang Wickler. The first refers to the concept of man as a personal being, in which nature is "integrated in the person", the being that exists in continuous development by the substantial focus on personal well-being as the ultimate goal and motive. Natural law is interpreted as a reflection of the spiritual nature of man's eternal (unchanging) order, rational inclination of human nature into a good commensurate for personal existence. The second conceptcreated by Wickler from the position of the criticism to the "traditional" concept recognizes the physical and the spiritual unity of human nature, but the realm of morality, which is fundamental in personal life, and is based largely on the basis of biological inclinations, which are a kind of criterion of moral good. The result of such human understanding is the concept of the natural law of variable content (according to the evolving biological nature of human) and some kind of ethical biologism (strengthening the moral law in the law of nature understood biologically).

The problem of natural law, in a more or less visible form, is still present, especially in social and political debates about law, and one of the repeated point is the "traditional" concept. In this context, the objective of this article is to present one of its counter form which is in favor of the contemporary arguments for the "modern" understanding of natural law.

Keywords: natural law, natural law, human nature, neo-thomistic personalism, biologism.

DOI:10.7862/rz.2014.hss.64

Przesłano do redakcji: czerwiec 2014

Przyjęto do druku: grudzień 2015 